\title{
EAl Endorsed Transactions

\section{Towards low-carbon energy state in South Africa: a survey of energy availability and sustainability}

\author{
Paul A. Adedeji ${ }^{1, *}$, Stephen Akinlabi ${ }^{2}$, Nkosinathi Madushele ${ }^{1}$ and Obafemi O. Olatunji ${ }^{1}$ \\ ${ }^{1}$ Department of Mechanical Engineering Science, University of Johannesburg, South Africa. \\ ${ }^{2}$ Department of Mechanical and Industrial Engineering, University of Johannesburg, South Africa. \\ 2 Department of Mechanical Engineering, Covenant University, Ota Nigeria.
}

\section{Abstract}

The drive towards low-carbon economy in South Africa has necessitated alternative energy sources for electricity generation. More alternative sources have evolved in recent times with a view to making energy available to all and sundry. However, asides proliferation of these sources and extensions in form of micro-grids, the questions of increased availability and sustainability has become a growing concern. This survey investigates the state of the renewable energy system in South Africa with focus on the elements, which enhance energy availability and sustainability in the emerging transition to a lowcarbon economy. Case studies of other countries were reviewed and considered in the South African context. It was observed that energy availability on the journey to the low-carbon economy is influenced by physical, climatic, human, prosumer concept and political factors. In sustaining the transition and progressing to a green economy, intelligent use of data from power generation, transmission, and distribution sectors for intelligent data-driven decision-making processes was also found as essential. As part of the sustainability roadmap, efficiency at the end-user side of the value chain and a system thinking paradigm in the harvesting of renewable energy sources (RES) and formulation of supporting policies were also identified. In the overall, the study reveals that South Africa is replete with abundance of RES, however, their continuous availability and sustainability depends on joint interventions of both stakeholders and the government with viable environment for the growth of the sector.

Keywords: Energy availability, energy sustainability, low-carbon state, renewable energy, South Africa

Received on 23 May 2019, accepted on 17 November 2019, published on 22 November 2019

Copyright @ 2019 Paul A. Adedeji et al., licensed to EAI. This is an open access article distributed under the terms of the Creative Commons Attribution licence (http://creativecommons.org/licenses/by/3.0/), which permits unlimited use, distribution and reproduction in any medium so long as the original work is properly cited.

doi: 10.4108/eai.13-7-2018.161751

\section{Introduction}

About $30 \%$ of the global energy generated is transformed into electricity [1]. However, population increase, economic growth, rural to urban migration and technological development have necessitated increased demand for energy in the form of electricity. International Energy Agency anticipate a $40 \%$ increase in global energy

*Corresponding author. Email: pauladedeji2k5@gmail.com consumption by 2040 [2]. South Africa, as a country has experienced a significant increase in electrification both in the rural and the urban areas from less than $33 \%$ in 1990 to $58 \%$ in $1996[3,4]$ and to about $90 \%$ in 2016 , success courtesy of government policies and interventions [5]. The country is ranked globally as the seventh largest coal producer with the primary type of coal explored being the bituminous coal $[6,7]$ The abundance of coal in the country has influenced her power sector as South Africa produces about $77 \%$ of its electricity from coal [8]. With the quest 
to ensure environmental sustainability and reduced emissions in the country, there is advocacy for the use of mitigation technologies like Flue Gas Desulphurization (FGD) plant in coal-fired power plants [9]. However, the FGD plants only reduces the flue gas emission; they do not eliminate them completely. Despite the country's huge reliance on her coal-fired plants as primary energy sources, it operates one of the highly successful Renewable Energy Independent Power Producer Procurement Programme (REI4P) globally, which has attracted renewable energy (RE) investors [10]. The REI4P established in 2011 [11] was aimed at incorporating more RE generation into the South African energy mix.

RE integration into the energy mix of the country has been systematically viewed as one of the potent means through which the country responds to climate change and energy security [12]. With all the policies developed to favour RE in the country, the question of the country's disposition to effective policy implementation is of high necessity. Notable in the country is the use of RES such as concentrated solar power (CSP), photo-voltaic (PV), wind, hydropower, biomass for power generation [13]. However, integrating more of these sources into the South African energy mix without adequate consideration of their sustainability makes them short-lived. RE projects have taken a good lift in South Africa [14], though more from the standalone perspective. Microgrids are fast springing up with new policies supporting their existence $[5,13,15]$. However, a cointegration of several RE sources in the national grid and government policies and support schemes to foster their increase and viability in the country need adequate attention.

In the last decade, the implementation of RES as substitutes for non-renewable sources for electricity generation in the country has been on the increase. Eskom, a government-owned electricity manager anticipates a 30 $\%$ power generation from $\mathrm{CO}_{2}$-free sources by 2030 [16]. However, wind, hydropower, PV, biomass and the CSP are still at the infant stage in their exploration for electricity generation in the country compared to the age-long coal fuel. With the integration of RES into the country's energy mix, there is an anticipated increase in the costs of coalbased power generation. This consequentially will increase the financial viability of RE technologies thereby causing a reduction in the power generation subsidy [17].

Mini-grids, microgrids, and small-scale RE projects have lately received preference in their use for electricity generation in South Africa. However, the question of how energy (electricity) sustainability and increased availability can contribute to the low-carbon transition is of keen interest in this study. While this section of the article introduces the topic, section 2 provides the methodology adopted in this survey and gives an overview of the present state of RE and low-carbon economy in South Africa. Section 3 focuses on energy availability and section 4 and 5 focuses on energy sustainability and availability measures respectively. Section 5 concludes the paper.

\section{Methodology}

In this study, a desktop literature survey was carried out on relevant and recent Scopus indexed articles from reputable journals. Recent reports and bulletins from the South African government and globally recognized energy-related databases were also consulted. Trends in energy-related concepts were identified and case studies of other countries were reviewed and compared with the South African case study. Deductions from these case studies were considered and applied to create a roadmap towards ensuring energy availability and sustainability as the country journey towards low-carbon economy.

\subsection{The Present State of RE in South Africa}

About six RES have been identified as feasible sources in South Africa. They include; solar, wind, hydropower, biomass, and tidal energy [8]. These identified sources vary in viability from one province to another. Shown in Figure 1 is the historical data of power generation from the three prominent RESs (hydropower, wind and solar) in South Africa collected from the South African Databank ${ }^{\dagger}$ from 1991 to 2015.

From Figure 1, energy from hydropower stations have offered a high prospect over the years. South Africa has three categories of hydropower plants: the runof-river (Colley Wobbles, First and second falls and Ncora), the conventional reservoirs (Gariep and Vanderkloof) and the pumped hydropower plants (Palmiet and Drakensberg) [18]. In 2012, a gradual increase in the harvesting of other RES (Figure 1) with hydropower contributing the highest (4.211 MWh) was observed. In recent years, more investments have been committed into solar energy harvesting both (PVs and CSPs) $[19,20]$.

In the present-day South Africa, the solar PV, CSP and wind energy resource lead the RE space. At the end of 2018, statistics show that a total of 2,078 MW of wind, 1,479 MW of solar PV, and $400 \mathrm{MW}$ of CSP in South Africa were in operation [21].

$\dagger_{\text {www.statssa.gov.za }}$ 


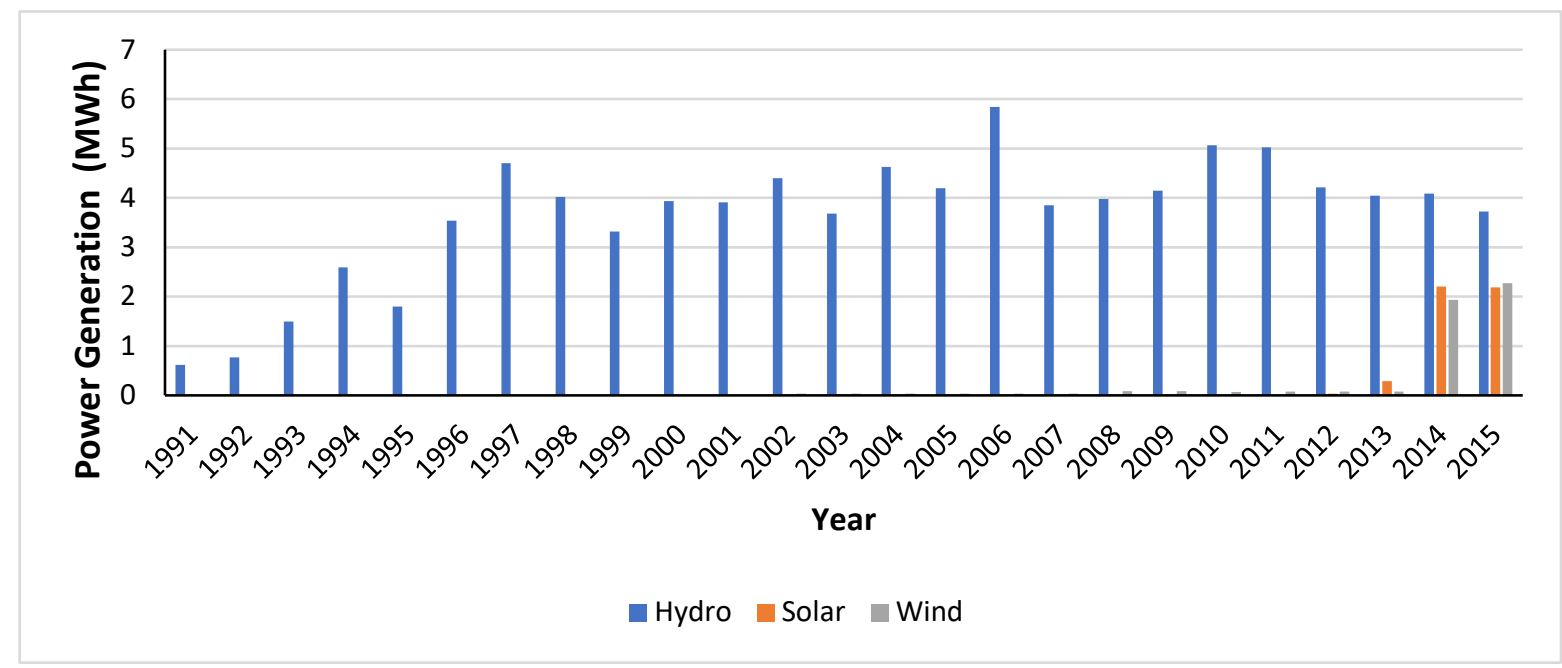

Figure 1. Power Generation from renewable sources from 1991 to 2015

These three RESs at the end of 2018 supplied 4.6 $\%$ of the South African energy system as shown in Figure 2. While there exists an increase in the amount of energy generated from wind energy and the CSP between 2017 and 2018, the amount of energy generated from solar PV remains the same in the two years. The constant percentage occupied by solar PV in the energy mix was as a result of the same number average amount of power generated from the fourth bidding window in 2017 and 2018. In the first quarter of 2019, a total of 3.0 TWh from a nexus of wind, solar PV, and CSP was produced and over $12 \mathrm{TWh}$ is estimated for the rest of 2019 [22]. Wind energy was conservatively estimated by van der Linde and Sayigh [23] in 1999 as having the potential of meeting approximately 5 $\%$ to $6 \%$ of the South African energy demand. The present status of the wind resource shows about $50 \%$ of this estimate. These reveal that the wind energy resource is still less explored in the country.

At provincial level in South Africa, RESs are widely dispersed with some provinces having higher prospect of a nexus of resources than the others. Shown in Figure 3 is a mapping of potential distribution of RES at provincial level. Efforts are been made to expand and validate this mapping using more reliable and accurate data.

With a focus on the growth of RE and low-carbon economy in South Africa, spaces of extrastatecraft, which provide exclusions to RE developers and investors were marked out

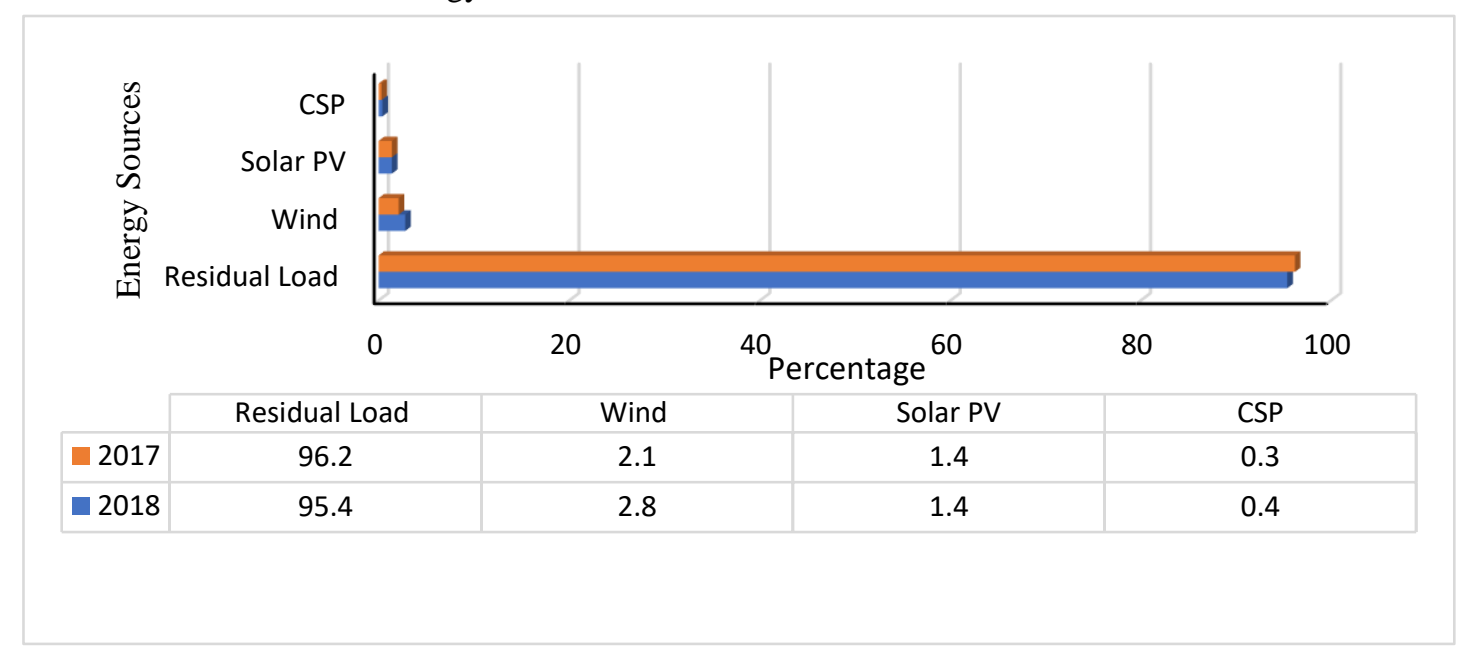

Figure 2. The percentage occupied by CSP, Solar PV, and Wind energy resource in 2017 and 2018 [20]. 
and called the renewable energy development zones (REDZs) [25]. The Department of Energy (DoE) in South Africa developed the first numerically verifiable wind

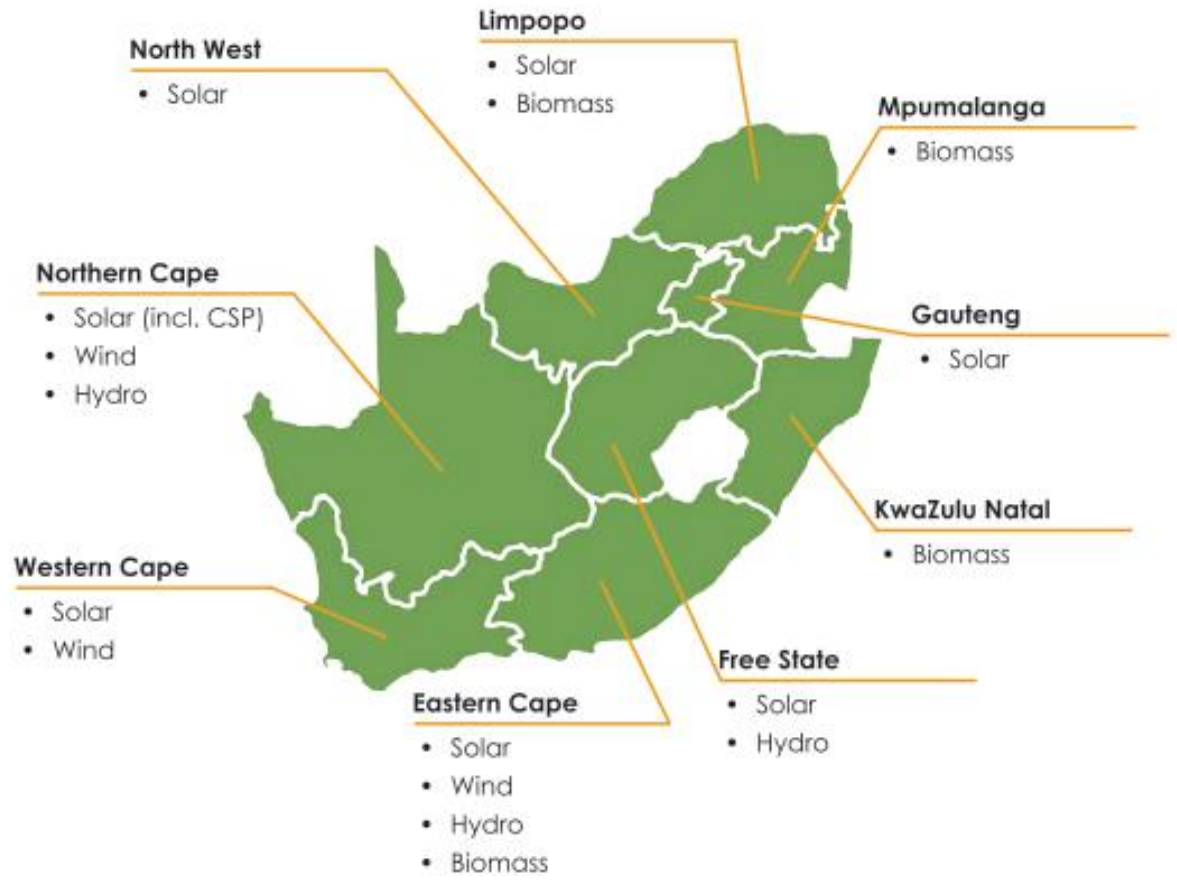

Figure 3. Renewable energy distribution at provincial scale in South Africa [23]

energy atlas for Phase 1 of the transition towards the renewable energy era for power generation. After the Phase 1 of the transition towards RE in the country by the Strategic Environmental Assessment (SEA) for RE growth in South Africa, the National Department of Environmental Affairs (DEA) approved the Council for Scientific Research (CSIR) to develop a large-scale high-resolution wind resource map for both wind and solar resources. The Phase 2 project was approved for gazetting in February 2016 [26]. Suitability analysis in the country for wind and solar energy was carried out using a multicriteria and multidisciplinary approach. The Phase 1 successfully identified eight (8) REDZs, which yielded global minimum for environmental impact and global maximum for resource economic and social benefit on the South African map. The Phase 2 project was aimed at identifying more REDZs and reviewing the four tiers sensitivity maps developed during the Phase 1 using recent datasets [27]. Several rounds of bids have been rolled out in the past few years and the development of farms rolled out in the Round 4 presently under construction and more rounds are still in progress.
Areas identified are still being explored by investors in the RE space. Despite the variability and intermittency of RES, the sector plays significant role in the South African electricity mix. Even though South Africa is not placed high in the use of RE compared to the Organization of Economic Cooperation and Development (OECD) countries and Africa as a whole, effort is being made to increase the share of the RE sources in the energy mix of the country [28].

\subsection{Low Carbon Economy}

A low-carbon economy is defined as, "A way of thinking, behaving and operating which minimizes carbon emissions while enabling sustainable use of resources, economic growth and improvement in the quality of life"[29]. This thinking focuses on both economic growth and environmental issues from resource efficiency and low-carbon products and services perspectives [30]. From the conceptual framework of Garza-Reyes and Juan Martinez [31], the low-carbon economy is a mid-way transition between the brown economy and the green economy as illustrated in Figure 4. Each transition from one economic state to another is replete with several integral stages and factors which culminates to determine which state an economy is. 


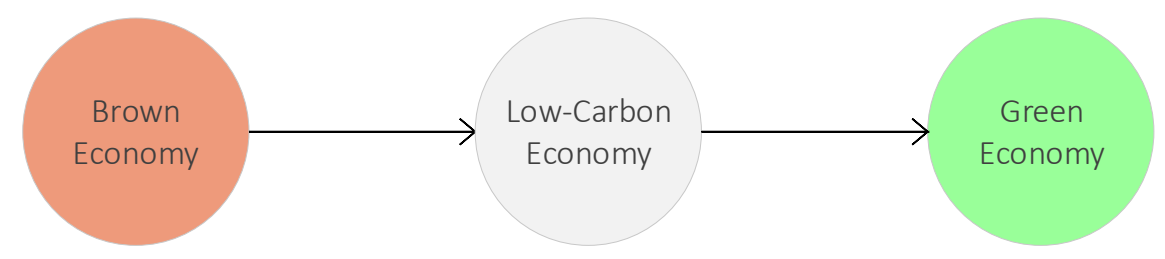

Figure 4. Economic transition by colour codes.

Anthropogenic activities have been on the increase since the first industrial revolution. Their effects have significantly affected the biosphere one of which is temperature increase. Therefore, keeping the average global temperature below a threshold of $1.5^{\circ} \mathrm{C}$, which is considered to be above the pre-industrial range [32] calls for deliberate effort in emission reduction. Low-carbon economy has been perceived as a bifurcated concept of either low-carbon production or a low-carbon consumption [33]. Its concept is hinged on efficient energy consumption and low pollution achievable with clean energy at the generation side of the energy value chain.
One of these is the policy support for power generation using RESs. More like it is the advocacy for efficient energy consumption along the energy value chain.

Low-carbon economy has become an irreversible global mantra, which all at the national level are meant to embrace to achieve its global impact before the reality of its non-compliance meets the global community. The pathway towards sustainable low-carbon transition is packed with several strategies.

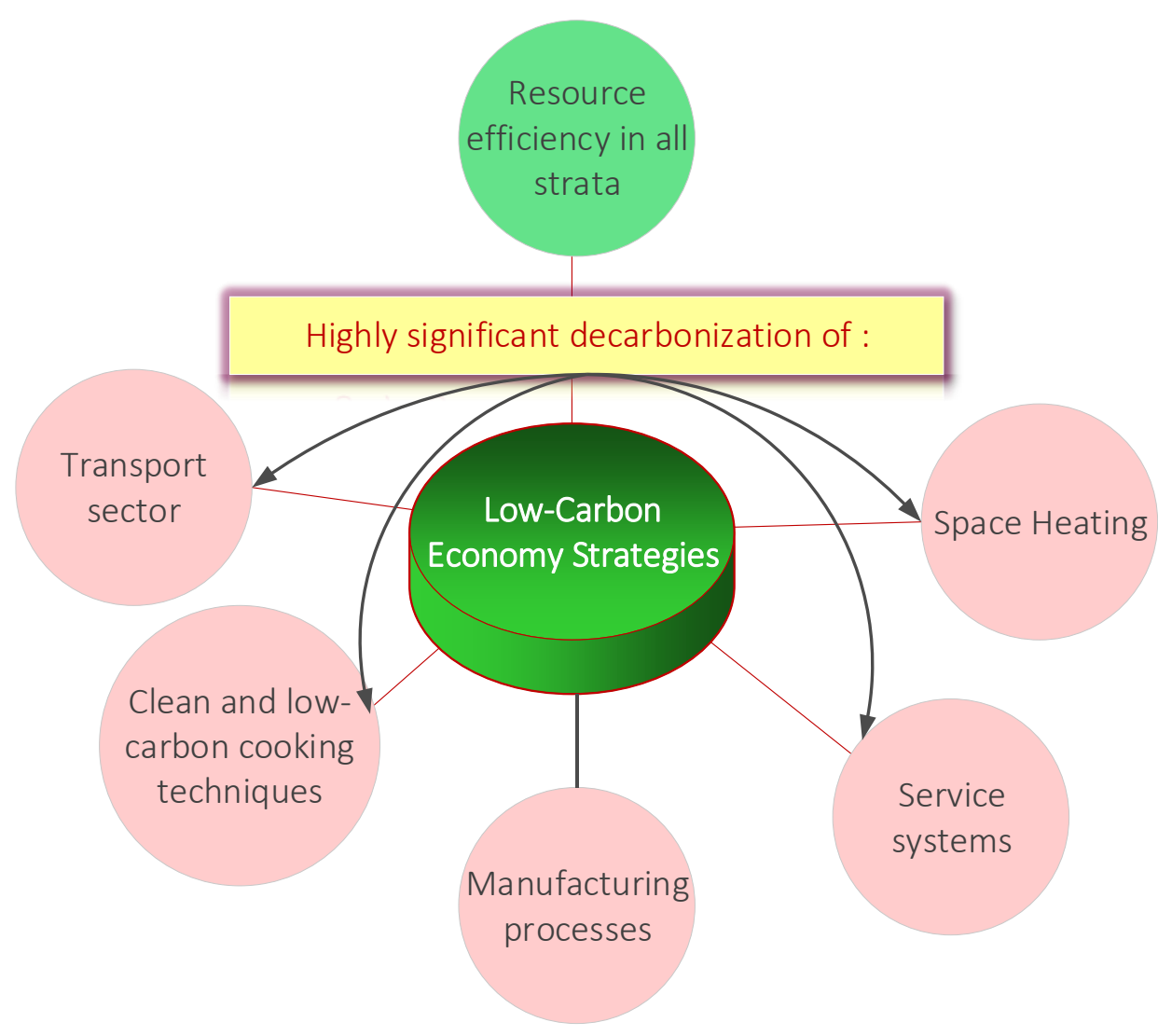

Figure 5. Strategies for low-carbon economy.

As one of the outcomes of the Paris agreement in December 2015, the global community aims at forestalling rise in temperature to about $2{ }^{\circ} \mathrm{C}$ [34]. In pursue of this, several measures have been put in place towards ensuring a low-carbon economy both at the global and national scale.
These range from high-level resource efficiency in all sectors directly and indirectly connected to energy [35], strong advocacy for engineered processes and services to deliver low-carbon-based products [36], highly significant decarbonization of the electricity generation sector [29], transportation sector (air, rail, road and water), 
highly significant decarbonization of heat systems, including space heating and strong advocacy for clean and low-carbon cooking technologies as shown in Figure 5. These networks do not significantly recognize the complex dynamics and strong interconnection between the existing systems due to their lock-in processes, which have developed a path-dependent clusters and entrapments over a long period of time [37]. At organisational level, advocacy and integration of climate change mitigation policies into the organisation's goals is fast becoming part of the corporate strategy [37].

Achieving a low carbon economy amidst the complex existing nexus of operational systems in a national economy has necessitated an identification of principal areas of change along the environmental impact scenario. Kane [38] from the technical point of view identified the principal elements that culminates into environmental impacts. These are the sources, the pathways and the receptors as shown in Figure 6. Mitigating these impacts involves either eliminating the receptors (which is a herculean task, e.g. eliminating waterbodies inside which wastes are illegally disposed), removing the pathways, thus creating a barrier which prevents impacts from the source from reaching the receptors (this could be done using mitigation technologies like the use of the FGD plants in coal-fired power plants), and the elimination of the source (which is more potent and feasible in practice). Presently, South Africa employs the use mitigation technologies along the pathways from source to receptors. This is observed in the use of FGD plants in some coal-fired power plants.
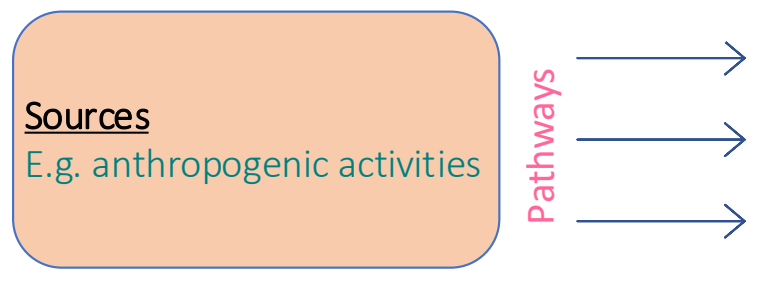

b. Entrenching an economy-wide carbon price by 2030 .

c. Enforcing the zero-emission building standards by 2030 .

d. Significant reduction in the yearly volume of waste disposed to landfill.

According to the Department of Environmental Affairs [40], the agenda 2030 depicted in Figure 7 can be divided into three phases which are the peak phase, the stationary emission phase and the decline phase. Before the peak period is the pre-2020 period where no emission limits are set at sectorial and company levels. The stationary and decline phases are embedded in the post2020 period where the climate change bill/act would have been formally approved by the government. These include carbon budgets and sectoral emission targets for individual companies and sectors respectively with strict measures to ensure compliance after which the dynamics of the carbon market in the country can be fully understood.

The agenda 2050 on the other hand aim at establishing an integration between the national and international commitments towards reduction of carbon emissions from the climate change, socio-economic and developmental perspectives. This is to be achieved through integrated energy planning for the country.

Presently, mitigation technologies are used with an increase in the integration of RESs into the country's electricity mix, however, the transport sector is still highly dominated with carbon-dominant liquid fuels. The space heating and cooking is also dominated by electricity and also by liquid, gaseous and solid fuels, which are associated with carbondioxide emission, though at different amounts $[35,36]$.

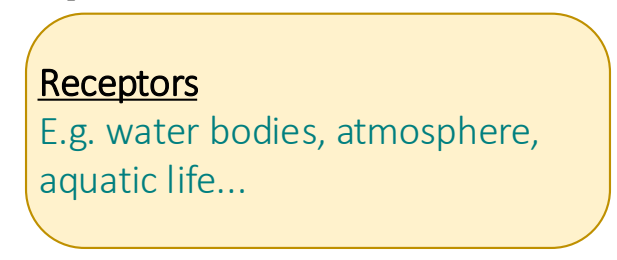

Figure 6. Environmental impact pathway

Stringent policies and effective monitoring of organizational compliance to low-carbon policies across all strata are being developed in several countries at national levels and also organizational levels of both manufacturing and service industries. South Africa being one of the most carbon-intensive economies, due to her huge reliance on coal-fired power plants for electricity generation, have adopted several strategies in a view to moving towards low-carbon economy [7,39]. Two agenda towards ensuring low-carbon economy in the country was identified in this study: agenda 2030 and agenda 2050 [40]. The agenda 2030 aim at:

a. Achieving the peak, a plateau and decline trajectory for greenhouse gas emission with the peak occurring at 2025 .

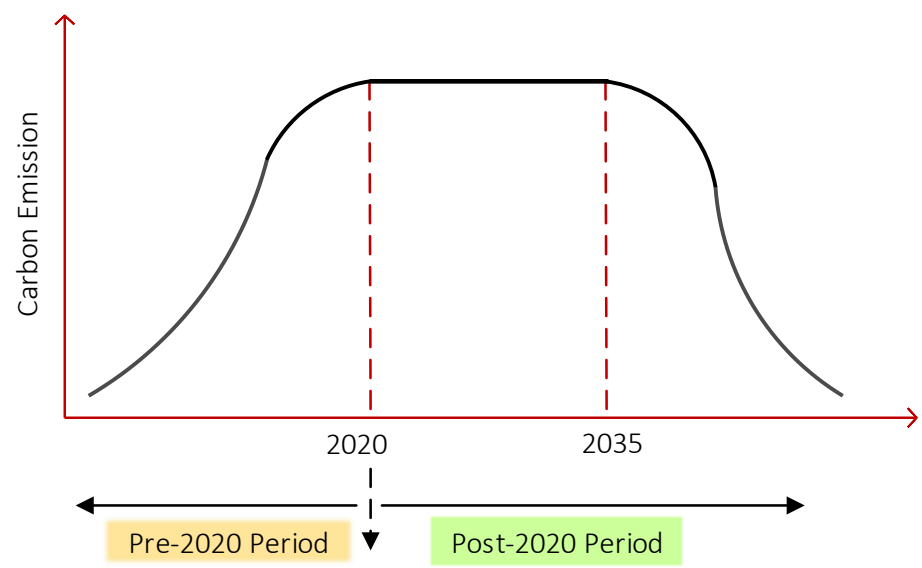

Figure 7. The 2030 agenda for carbon emission pathway. 


\section{Energy Availability}

Availability constitutes one of the hallmarks of energy in a country. Energy (electricity) availability is a significant factor in siting of industries and a cogent factor in socio-economic development [41]. Factors that constitutes availability varies from one energy resource to the other as well as from one geographical location to another. This section highlights the energy availability factors for RES as the country progresses towards a lowcarbon economy. Four of these factors relevant to the South African case study were discussed in this study.

\section{a. Physical Factors}

Several physical factors militate against RE availability in South Africa. One of these factors is siting RE plants in energy hotspots close to the point of source [42], with investors operating only at the designated REDZs.

RES are known for intermittency and variability [43-45], which militate against their reliability. However, maximizing the available RES requires locating energy harvesting facilities in energy rich sites. Most of the country's coal-fired plants are sited in the northern part to minimize the transportation of coal from mining sites to the power plants. Same practice for RES increases efficiency of the harvesting technologies and minimizes transmission losses [46].

Asides viability of geographical areas for RES prospects, several criteria are involved in siting RES plants which include economic, environmental, socio-political [47] and technical criteria. These result into a multi-criteria decision making (MCDM) problem, often solved by known techniques such as Analytical Hierarchical Process (AHP), Fuzzy Technique for Order Processing by Similarity to Ideal Solution (Fuzzy-TOPSIS) and so on. Suitability analysis of geographical locations applies spatial geographical information systems to spatially locate RE plants for power generation. The mapping in Figure 2 shows that every province has potential of generating energy from at least one RES even though the national energy demand and available supply relationship should be critically examined. However, distributed system which harnesses RE potentials per province is fundamental to energy availability in the country.

\section{b. Climatic factors}

The wind and solar energy are two RESs largely explored presently in South Africa. The availability of these sources significantly depends on climatic factors associated with their operation. After a careful site suitability analysis is carried out on a resource hotspot and less environmental impacts during operation is ensured, the climatic condition of the wind or solar farms largely affects the active power of the energy harvesting technology.

For example, for a wind turbine, availability of the wind resource largely depends on the wind speed per time, whose variation is largely influenced by weather patterns [48]. In South Africa, the seasonal variation in the movement of air masses significantly varies between the summer and winter seasons. During summer period, the south-east trade wind influences the north-eastern part of the country and as such, increased wind speed is observed around the Limpopo province across to the Free State Province. Also, the south-east trade winds resulting from the ridging of the South Atlantic High is observed to the strong and persistent and hence influences the southern, western, and the south-eastern coastal areas and its adjacent interiors. However, in the winter seasons, the wind circulation is observed more in the north. Strong cold fonts that moves mostly over the southern half of the country and its ridging high-pressure systems results in strong winds during the winter season. The cold fonts often significantly travel over the southern and central part of the subcontinent and more likely through to the north. The strong westerlies consequentially have its area of influence within the southern, western, and the south-eastern coastal areas including the adjacent interior. The strong movement of the Atlantic high pressure towards the east can result in gale force winds spreading to the KwaZulu Natal coast and even through to the Mozambique channel [48]. Shown in Figure 8 is the South African wind resource map at $100 \mathrm{~m}$ height. 


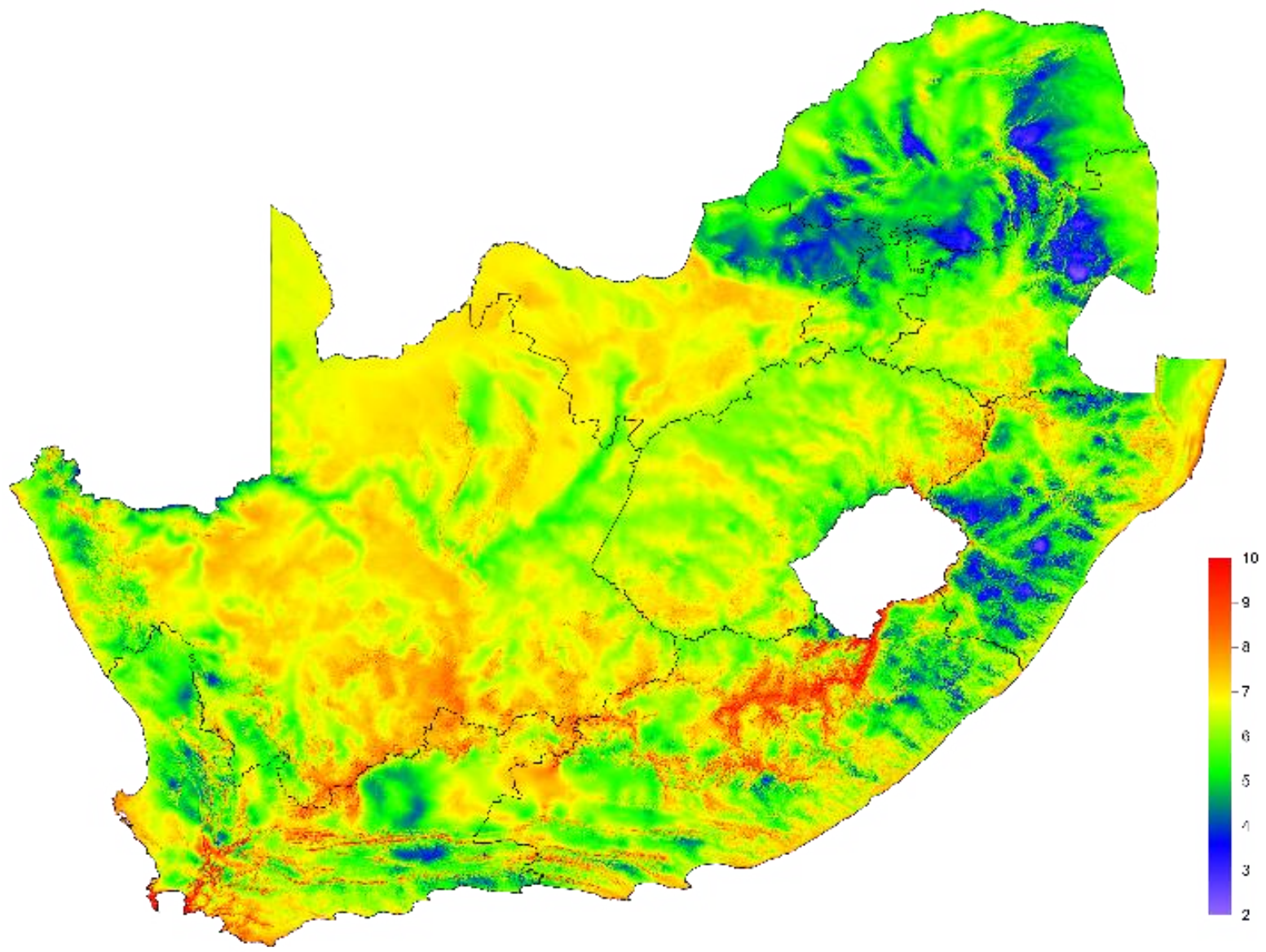

Figure 8. The South African wind resource map at $100 \mathrm{~m}$ height.[49].

Similarly, the solar resource in South Africa is a geospatial variant; it is abundant with higher irradiance in certain provinces and not in some others. It has been established that South Africa has one of the highest solar irradiance as well as yearly horizontal solar irradiation on the global scale. On the average, daily solar radiation in South Africa falls between 4.5 and $6.5 \mathrm{kWh} / \mathrm{m}^{2} /$ day as compared to about $3.6 \mathrm{kWh} / \mathrm{m}^{2} /$ day observed in some parts of the USA and about $2.5 \mathrm{kWh} / \mathrm{m}^{2} /$ day experienced in the United Kingdom and Europe [50,51].

A comparison between Industrialized countries harnessing solar energy at larger scale shows that South Africa province with the lowest potential possess a higher level of solar irradiation than these countries [52]. A study by Fluri [53] shows that five of the nine provinces in South Africa (Northern Cape, North West, Eastern Cape, Western Cape, and Free State) has annual average direct normal irradiation higher than $7.0 \mathrm{kWh} / \mathrm{m}^{2} /$ day. In the study, the Northern Cape has the highest potential for concentrated solar power (CSP) facility with a total area of $14,288 \mathrm{~km}^{2}$ viable sites. Table 1 shows the South African solar potential compared with some selected global locations. The feasibility of PV plant location is dependent on several factors like temperature, direct normal irradiation, cloud cover and so on. Figure 9 shows a map of solar PV resource potential in South Africa.
Table 1. Comparison between the annual radiation potential of South Africa and other selected countries.

\begin{tabular}{lll}
\hline Location & $\begin{array}{l}\text { Site } \\
\text { Latitude }\end{array}$ & $\begin{array}{l}\text { Annual } \\
\text { Radiation } \\
\left(\mathrm{kWh} / \mathrm{m}^{2}\right)\end{array}$ \\
\hline $\begin{array}{l}\text { South Africa } \\
\text { Upington, Northern } \\
\text { Cape }\end{array}$ & $28^{\circ} \mathrm{S}$ & 2,995 \\
The United States & & \\
Barstow, California & $35^{\circ} \mathrm{N}$ & 2,725 \\
Las Vegas, Nevada & $36^{\circ} \mathrm{N}$ & 2,573 \\
Albuquerque, New & $35^{\circ} \mathrm{N}$ & 2,443 \\
Mexico & & \\
& & \\
Other Countries & $26-30^{\circ} \mathrm{N}$ & 2,835 \\
Northern Mexico & $30^{\circ} \mathrm{N}$ & 2,500 \\
Wadi Rum, Jordan & $31^{\circ} \mathrm{N}$ & 2,364 \\
Quarzazate, Morocco & $35^{\circ} \mathrm{N}$ & 2,293 \\
Crete & $26^{\circ} \mathrm{N}$ & 2,200 \\
Jodhpur, India & $34^{\circ} \mathrm{N}$ & 2,100 \\
Spain & & \\
\hline
\end{tabular}

Source: [55] 


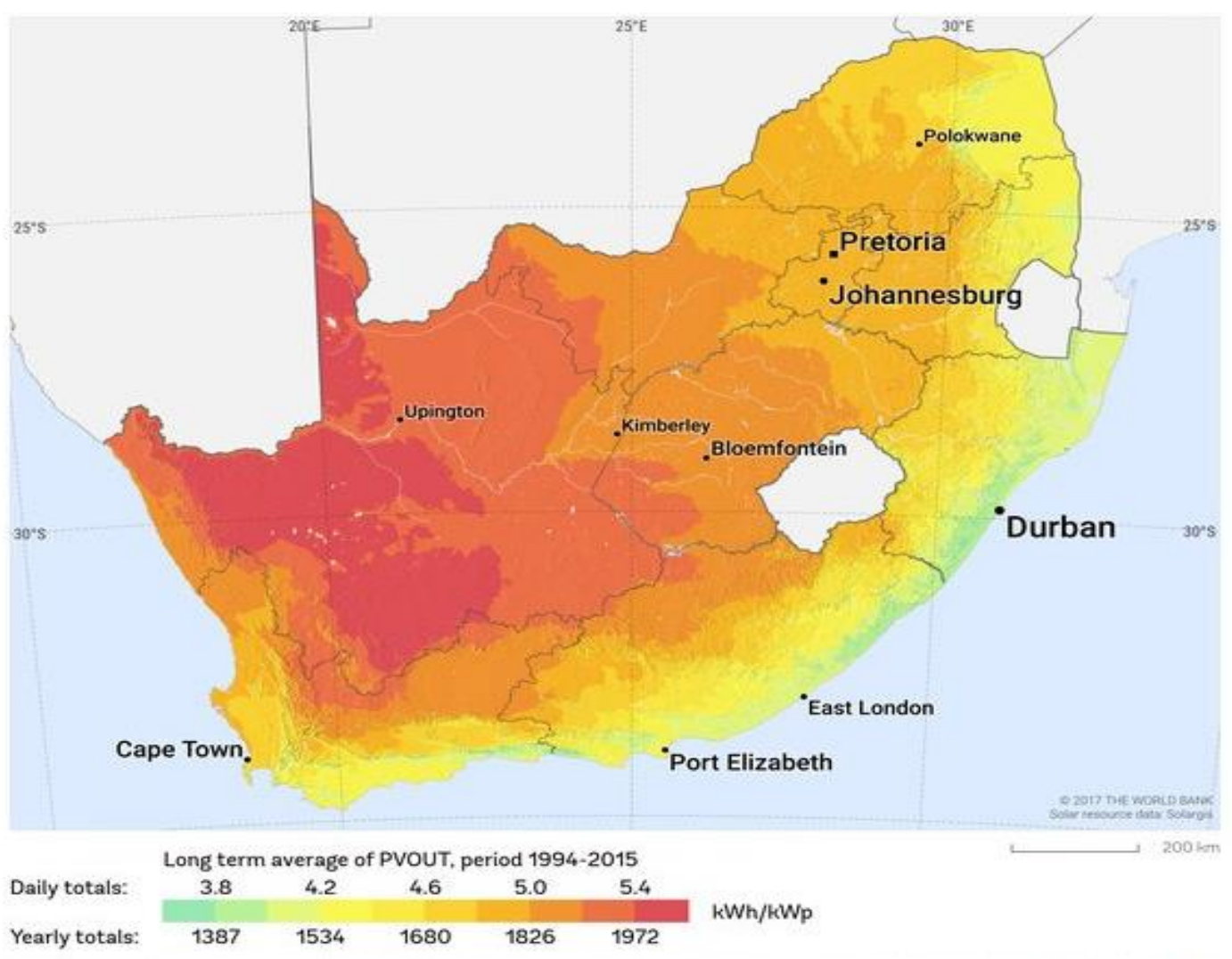

Figure 9. South Africa's photovoltaic resource potential. [54]

Several studies on South Africa renewable energy status has established variation in Solar and Wind energy across the country's nine provinces, which has significant effect on their harnessing for power generation [52,56,57].

\section{c. Human Components}

One of the non-deterministic components which affects energy availability is the human component. The human component of the energy sector is a psychological variable, which varies globally from one geographical location to another. The energy sector, regardless of its level of automation, still requires human inputs either at operational, strategic, or administrative level to a certain degree. Decision making, physical monitoring, and facility management are primarily done by humans to a higher degree.

Certain human dynamics affects the productivity of industrial organizations which power generation industries are not exceptions. These dynamics has consequential effects on the energy availability, which could affect productivity and profitability of the system. Some of these dynamics are the personnel's attitude to work and the skillset. Regarding the attitude to work, mental and muscle power is necessary for organisational development; however, the will power has a tendency to overrule these. A study by Surender [58] on the attitude of South African paid workers to work and social grants reveals about $78 \%$ of the paid workers having a notion of hanging on a job even when it is not of your interest. The study was carried out on 39 focus groups in the Eastern Cape and the Western Cape Provinces and comprises a total of 386 respondents. Similar study with a total of 2,885 South Africans across the nine provinces shows that about two-third of the employed expresses a level of satisfaction with their job, however, Black African workers remained less satisfied with their jobs than their white counterparts [59,60]. Mncwango [59] stated that job satisfaction, measured in terms of tends to increase with age, social status and the level of education and a higher degree of job satisfaction is noticed in the men than in the women. Since job satisfaction is directly proportion to productivity, an unsatisfied workforce is most likely to negatively affect the energy system in terms of availability with a ripple effect on the country's economy.

In term of skill, even though the country is increasingly developing local citizens in the renewable energy industry, the absence of enough manpower with requisite skills in the renewable energy space who can take up the upcoming energy challenge is still prevalent. Although South African Renewable Energy Technology Centre (SARETEC) is taking the lead in this regard, there are still so much to be done. The institution is immensely contributing to the growth of RE in the country by providing requisite industrial skills to participants specifically in the solar and wind energy space, however, 
the cost of training is considered significantly high for many citizens and participation in the trainings often requires a sponsorship for students. To foster energy availability in the country in the coming energy transition, there is need for local competent personnel with necessary skills in the supply chain of RES from cradle to grave. This would reduce the overhead cost and in turn could reduce the electricity tariff but most importantly increase system availability.

\section{d. Prosumer concept and policy}

The prosumer concept represents the dual nature of energy consumers not only consuming but also producing even if it is in micro-scale. It is obvious from Figure 2 that every province in South Africa has one or more renewable energy resources which can be harnessed in small or large scale. The use of solar powered heaters not only reduces energy consumption from the grid in its use but also reduces cost of energy on the part of its users. Availability of biomass feedstock in all provinces is established [19] even though this may not be available on a commercial scale across all provinces. Small-scale biodigesters in homes reduces electricity cost expended on space heating and cooking. However, the efficiency of the prosumer concept lies on supporting government policies. Gleaning from prosumer schemes from other countries, we considered a study by Inderberg et al. [61] conducted on Norway, Germany, and the United Kingdom (UK). The study investigated the vital factors that increase the number of prosumers in the energy sector. The study investigates direct regulatory provisions, support schemes and the thirdparty installer markets. While the introduction of thirdparty installation markets in all the three countries increased the numbers of prosumers, this factor was observed to be dependent on support schemes. The number of prosumers was observed to increase in economies ardently in need of decarbonization as in the case of Germany and the UK. Regulatory factors in the form of licenses, pricing, was observed to also depend on support schemes from each of the countries. Adequate support schemes which fosters prosumerism could be adopted in the South African case study, thus increasing the level of decarbonization and energy availability. Small-scale embedded generation is encouraged by the country since the relaxing of the Electricity Regulation Act in the year 2007, which allows feed-in to the grid [62]. However, policies which accrues incentives to small-scale embedded generation has great prospects on the journey to the low carbon state. By this, manufacturing industries will not only experience reduction in their carbon footprints but also cut down on their carbon tax bills at the end of each fiscal year.

The prosumer business models are hinged on five (5) categorical key principles as identified by Brown et al. [63]. These include; the customer interface (customer's integration in the model design phase), value proposition (service delivery across multiple energy vectors can increase higher value creation and capturing), the supply chain (prosumer business models must positively improve existing energy value chain as it still depends on it despites its high level of decentralization), financial model (revenue increase for new prosumer models can be achieved by: increase in self-consumption behind the meter; price improvement on exported power; ensuring litheness, balance and improvement in ancillary service market; a shift in energy vectors asides electricity) and governance (explicitness of government policies on energy). More on these principles can be found in [63].

\section{e. Political Factors}

The political factor forms one of the major key issues in the energy sector and significantly determines both energy availability and sustainability. Reform, policy adoption, and bills are positively related to each political era and so can be drivers or barriers to energy availability. Energy reforms and policies on energy access is more likely to be risky in a country with one-party rule or a limited electoral competition [64-66]. In the energy sector, the organisational structure of regulatory bodies and the degree of autonomy of elected political institutions influences the degree of regulatory risks and existing policies [67]. This is because increased autonomy among regulators may likely resist political pressures. It was argued by de Jongh [68] that clear and favourable political climate in the form of clear policies and well-defined RE objectives predicates the viability of RE investments. The South African government energy policy as stated in the 1998 [69] and 2003 [17] white papers from the Department of Minerals and Energy, was geared towards the following: (a) increased access to affordable energy services (b) fostering economic development (c) managing environmental impacts associated with the energy sector (d) improvement on energy governance (e) energy security through diversification of sources. With this in place, the country has been on the train by encouraging renewable energy integration into the country's energy mainstream. The post-apartheid era in South Africa gave an emergence to the country's Renewable Energy Independent Power Procurement Programme (REI4P) aimed at installing $17.8 \mathrm{GW}$ electrical power into the country's mainstream using RES comprising the wind, solar, biomass, hydropower, and biogas by 2030 [14]. While gradually planning to phase-off the coal power plant [7], it is anticipated that jobs will be lost from the present coal plants during the transition. The present unemployment rate in the country stands at $25 \%$ with the economic development plan aiming at about 300,000 jobs to be created in the green economy [70]. Creation of more jobs and retention of the existing jobs have been place on priority list of political campaigns [70], hence the reluctance is observed in the phasing-off of ageing coalfired power plants, which have consequentially affected the transition from the brown economy to the low-carbon economy in the country.

However, the South African National Development plant 2030 (NDP 2030), with employment goals as one of its aims, has favoured governmental support 
for REI4P. Although the first two rounds of the REI4P have successfully integrated new and smaller companies in the renewable energy space into the power sector, the big renewable energy companies have also benefitted in the subsequent rounds, however, improved policy is highly essential to ensure the relevance of small bidders. This is expected to have impact on the tariff, diversification, and proliferation of renewable sources in the energy mix, thus accelerating the low-carbon transition and increasing energy availability in the country.

\section{4. $\quad$ Energy Sustainability}

Sustainability has been defined by World Commission on Environmental Development (WCED) as "Development that meets the need of the present without compromising the ability of the future generations to meet their own needs" $[71,72]$. Sustainability in energy system is vital to its continuous supply and in turn affects national economy. Energy sustainability is a tripartite concept which includes economic, social and environmental sustainability pillars. This section considers some measures toward ensuring energy sustainability in South Africa relative to the three pillars of sustainability.

\subsection{Intelligent data mining and warehousing}

Power generation to final consumption by end user produces a large pool of data along the supply chain, which when harnessed makes the system more efficient and reliable. The journey towards low-carbon state requires efficient use of data for system sustainability considering the non-deterministic nature of energy consumption $[35,36]$. As one of the indices of cyber-physical systems, data mining holds a crucial role in achieving a sustainable RE system [73]. This in turn fosters economic sustainability of the energy system as data-driven decisions can be made for increased profitability across all the tiers involved in the electricity delivery to the end-user. The various data mining techniques functions as either a predictive or descriptive technique as shown in Figure 10 with each technique performing different functions in the process. This survey emphasises the relevance of the predictive model in energy sustainability. We consider the three phases of energy system; the generation, transmission, and distribution and how these three relate to the end user.

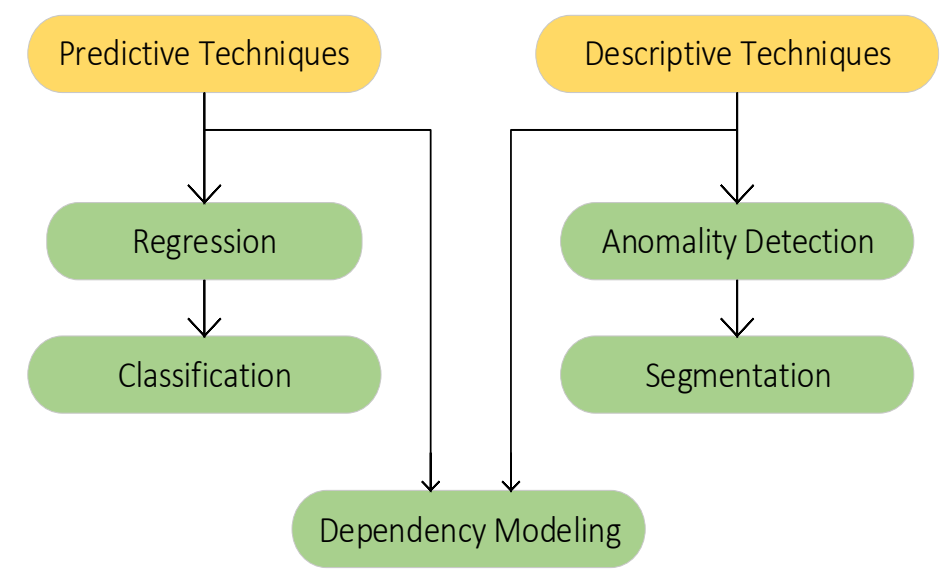

Figure 10. Classification of data mining techniques based on functionality.

\subsubsection{Generation}

A revolution in power generation system is noticed over the past decade. Power generation plants now operates on Supervisory Control and Data Acquisition (SCADA) system, which gives the state of the system in real time. Condition monitoring, as well as easy troubleshooting, is enhanced with this system put in place $[74,75]$. Despite a shift to the SCADA system, many power plants only store data acquired on an integrated database without fully harnessing its power at both operational and strategic decision-making levels. In order to enhance sustainability of RES plants, the concept of machine learning to unravel hidden patterns of data must be implemented at the design stage of the plants. A system which reveals the rate of production relative to set daily demand target to be fed into the transmission system is highly essential. The system must be capable of intelligently performing a sensitivity analysis of the effect of increasing generation above threshold on the lifecycle of the plant, both at system and component level. For sustainability, the SCADA system must readily integrate the power plant with data from external environment such that the effect of environmental conditions can be quantified on the system's performance in real time. Integrating weather forecast will foster the efficiency of the plants, to predict when energy is available for transmission unit both at long term and short term. All these capabilities and more are strongly dependent on an efficient and effective data mining system.

In South Africa, data mining and its efficient use on the SCADAs of both independent power producer (IPP) plants and other subsidiary plants offer a great potential in ensuring a reliable electricity. Real-time nowcasting and forecasting can be performed with real-time intelligent condition monitoring and robustness in the operation of generation plants using highly effective artificial intelligent algorithms. Presently in the country, data from generation plants have been under-utilized. Its efficient use will foster economic sustainability in the form of minimization waste 
in the system, environmental sustainability through reduction in emission as optimal production schedule will be religiously followed, and the social sustainability in the form minimization and maximization of negative and positive impacts respectively on the immediate community.

\subsubsection{Transmission}

Transmission system connects the generation and the load in an interconnected manner ensuring seamless delivery and enhanced reliability. Renewable energy systems for electricity generation are commonly operated in the form of microgrid, or mini-grid systems; only a few countries run on RES as the major grid. In such case, a nexus of the sources is used. Most often, electricity is transmitted through long distances at high voltage and low current to reduce losses. Data from the transmission system of electricity in terms of losses during transmission to substations and frequency of failures of interconnected grids can be used to redesign the RE system. RES, which are associated with intermittency in harvesting, requires a maximum use of the generated energy, hence losses due to transmission should be grossly reduced. The practice of embedded generation, such that energy is generated close to its point of use is therefore encouraged.

Also, increasing energy sustainability in the power transmission space requires real-time monitoring. Condition monitoring of the transmission lines for on-line fault diagnosis and the monitoring of this echelon in the electricity supply chain is essential. This will require online learning of faults and system conditions using intelligent empirical models. The effectiveness of these models is, however, hinged on effective data capturing, processing, storage, and retrieval. Eskom, being the eleventh largest power utility company on the global scale dominates the electricity sector of South Africa generating over $90 \%$ of the country's electricity. The company has $26,000 \mathrm{~km}$ of transmission lines cutting across the country and extending to most Southern African Development Community (SADC) countries [76]. Integrated data logging on this domain can be useful for condition monitoring to ensure grid stability as well as useful life prediction of infrastructure within the transmission space.

\subsubsection{Distribution}

Asides minimizing power losses at the distribution phase of electricity, which often results from resistance in electric cables, fraud, instrumental errors [77], an efficient data management system determines the economic viability and technical sustainability of this phase. The electricity distribution network of South Africa is mainly carried out by more than 278 municipalities [78]. These supply electricity to end users, which comprises domestic, industrial, and commercial consumers. Data of who buys what are generated on daily basis from procurement outlets. These data can be harnessed to determine:

i. The number of households that purchased electricity within a specific period. ii. The number of households connected to the grid and did not purchase between a time frame. This will help to detect leakages, illegal connections, and easy fault tracing, as this is the practice in certain areas.

iii. The consumption in the next fiscal year considering the rate of increase in electrification and buildings. Such data will help to forecast consumptions per sector for strategic planning both for distribution network as well as generation network.

iv. Real time effect of outages from planned and unplanned maintenance and other causes, which can be observed from consumers resistance and complaints.

v. A total quality management system, which entails customer satisfaction, quality of service with six sigma concepts can built from data obtained from this unit.

Electricity sector, like other business enterprises, is established to meet the needs of consumers and make profit in the process. All these at the distribution level enables the electricity sector to remain economically sustainable.

\subsection{End-user energy consumption}

South Africa has been an energy-intensive country contributes about $1.1 \%$ to the global greenhouse gas emissions and environmental pollution [79]. This effect has been linked to the inefficient use of the energy produced at all strata [80]. It is internationally established that saving a unit of energy is cheaper than producing one unit of energy [62]. Data from end user is relatively out of the loop, however, this can help in building energy efficient devices for end-user community. Data, in the form of energy consumption within a specific time, enables user to plan and optimize budget for same period. Asides the development of smart meters, energy consumption data from end user will help to build more efficient energy optimizer for end users. This can also help to eliminate standby energy consumption from plug load devices.

In the South African case study, many homes in the metropolitan cities have prepaid smart meters installed in their homes except some houses in the townships. The current smart metering in the end-user domain quantifies the real-time energy consumption as calculated from the voltage, phase angle, and frequency in the system. However, smart metering devices capable of bidirectional communication of energy consumption from the user to the supplier with data-logging facilities for user data-driven decision making is essential.

\subsection{Systems thinking}

Systems thinking emphasizes the nonlinear and dynamic nature of causes and effects [81]. Systems 
thinking approach enables both policy makers and operational level of decision making to visually consider the bipolar effect of every action. To ensure sustainability of RE system, the concept of systems thinking should be practiced at all levels of energy production from cradle to grave. The energy system is a complex system with several components interacting to produce the behaviour of the system. The complexity of the system increases as the number of components in the system increases. The journey towards low-carbon state entails a hybrid renewable energy system. System thinking considers not only the benefits of these sources but also the disbenefits within the causal loop. It considers the ripple effect of siting RES plants on the biosphere. Conceptualization of a system as holistic analysis and synthesis forms the bedrock of systems thinking [82]. Analysis of component factors involved in RE system, which include the environmental, economic, socio-political, and technical criteria and a synthesis of them all gives a holistic picture of the RE system.

For the South African case study, a critical evaluation of the power sector in its transition to the lowcarbon state is highly essential. The question of the effects of the transition to low-carbon economy on other sectors when the country's economy is driven by RE sources requires an honest answer. The pros and cons of this transition should be weighted in a causal loop manner, thus unravelling salient effects likely to erupt over time. Further studies on the renewable energy dynamics of South Africa using systems dynamics approach is greatly encouraged. This will not only unravel latent variables but also improve strategic planning and policy formulation in the energy sector.

\section{Conclusions}

Low-carbon energy state in South Africa is an achievable feat, however, its realization is hinged on viewing potential alternative energy sources from the standpoint of availability and sustainability. This study has highlighted several factors which contribute to energy availability and sustainability on the journey towards lowcarbon economy in South Africa. Renewable power generation on a large scale also involves the tripartite energy phases: generation, transmission, and distribution. A holistic view of the three with a view to harnessing data obtained from each process for strategic and operational planning predicates a sustainable low-carbon South Africa. Consumer efficiency and system thinking concept in energy system fosters the use of scarce energy resources in an efficient manner with an awareness of positive and negative impacts of misuse. On the overall, the peak of energy availability and sustainability in South Africa is an achievable feat, however, its realization is centres around an efficient synergy between all energy components in the energy system dynamics. Integration of artificial intelligence tools in the RE space is open for further research in South Africa. This not only ensures data-driven and informed decision making towards ensuring a lowcarbon economy in the country but also a strategic roadmap to a robust and sustainable energy system in the country.

\section{References}

[1] Putrus G, Bentley E. 20 - Integration of distributed renewable energy systems into the smart grid. In: Rashid MHBT-ERES, editor., Boston: Academic Press; 2016, p. 487-518. doi:https://doi.org/10.1016/B978-0-12804448-3.00020-7.

[2] EIA. International Energy Outlook 2017 Overview. 2017.

doi:www.eia.gov/forecasts/ieo/pdf/0484(2016).pdf.

[3] Monyei CG, Adewumi AO. Demand Side Management potentials for mitigating energy poverty in South Africa. Energy Policy 2017;111:298-311. doi:10.1016/j.enpol.2017.09.039.

[4] Marquard A, Bekker B, Eberhard A, Gaunt T. South Africa's Electrification Programme, an overview and assessment. 2007.

[5] Monyei CG, Adewumi AO, Jenkins KEH. Energy (in)justice in off-grid rural electrification policy: South Africa in focus. Energy Res Soc Sci 2018;44:152-71. doi:10.1016/j.erss.2018.05.002.

[6] Hancox PJ, Götz AE. South Africa's coalfields - A 2014 perspective. Int J Coal Geol 2014;132:170-254. doi:10.1016/j.coal.2014.06.019.

[7] Dunmade I, Madushele N, Adedeji PA, Akinlabi ET. A streamlined life cycle assessment of a coal-fired power plant: the South African case study. Environ Sci Pollut Res 2019. doi:10.1007/s11356-019-05227-6.

[8] Jain S, Jain PK. The rise of Renewable Energy implementation in South Africa. Energy Procedia 2017;143:721-6. doi:10.1016/j.egypro.2017.12.752.

[9] Candice S, Mathe T, Hart A, van Heerden C. Large scale Implementation of WFGD in Eskom: The Medupi Power Station WFGD Plant. FFF Anu. Waterb. Conf., 2014.

[10] Ministry of Lands Mines and Energy. Renewable Energy and Energy Efficiency Policy and Action Plan. 2016.

[11] Davies M, Swilling M, Wlokas HL. Towards new configurations of urban energy governance in South Africa's Renewable Energy Procurement Programme. Energy Res Soc Sci 2018;36:61-9. doi:10.1016/j.erss.2017.11.010.

[12] WWF-SA. Renewable energy vision 2030 - South Africa. Clim Chang Energy 2014:1-48.

[13] Aliyu AK, Modu B, Tan CW. A review of renewable energy development in Africa: A focus in South Africa, Egypt and Nigeria. Renew Sustain Energy Rev 2018;81:2502-18. doi:10.1016/j.rser.2017.06.055.

[14] Richard D, Colin A. Renewable energy gathers steam in South Africa. Renew Sustain Energy Rev 2015;41:390401. doi:10.1016/j.rser.2014.08.049.

[15] Rosenberg S a, Winkler H. Policy review and analysis: Energy efficiency strategy for the Republic of South Africa. J Energy South Africa 2011;22:67-79.

[16] Eskom. Partnering for a sustainable future: Integrated report 2011. 2011.

[17] Department of Minerals and Energy. White Paper on Renewable Energy. 2003.

[18] Eskom. Hydro electricity in South Africa. vol. 5. 2017. 
[19] Liu M, Koen H, Pantaleo AM, Guo M. Optimisation of Integrated Bioenergy and Concentrated Solar Power Supply Chains in South Africa. 28th Eur. Symp. Comput. Aided Process Eng. Graz, Austria., 2018, p. 16. doi:10.1016/B978-0-444-64235-6.50255-2.

[20] Calitz J, Mushwana C, Bischof-Niemz T. Statistics of utility-scale solar PV, wind and CSP in South Africa in the first half of 2017. 2017.

[21] Calitz J, Mushwna C, Dr Bischof-Niemz T. Statistics of utility-scale solar PV, wind and CSP in South Africa in 2018. 2019

[22] Wright J, Calitz J. Brief analysis of variable renewable energy contribution during loadshedding (Q1-2019). 2019.

[23] Linde HA Van Der, Elizabeth P, Elizabeth P. The economics of wind energy in South Africa. Renew Energy 1999;16:869-71. doi:10.1016/S09601481(98)00290-0.

[24] Department of Energy. State of Renewable Energy in South Africa. 2015. doi:9781920435080.

[25] McEwan C. Spatial processes and politics of renewable energy transition: Land, zones and frictions in South Africa. Polit Geogr 2017;56:1-12. doi:10.1016/j.polgeo.2016.10.001.

[26] SANEDI. Delivering Sustainable Energy Access. 2016.

[27] CSIR. Delineation of the first draft focus areas for Phase 2 of the Wind and Solar PV Strategic Environmental Assessment Prepared. 2017. doi:10.1002/ejoc.201403115.

[28] Nakumuryango A, Inglesi-Lotz R. South Africa's performance on renewable energy and its relative position against the OECD countries and the rest of Africa. Renew Sustain Energy Rev 2016;56:999-1007. doi:10.1016/j.rser.2015.12.013.

[29] The Scottish Government. A Low Carbon Economic Strategy for Scotland A Low Carbon Economic Strategy for Scotland. Edinburgh: The Scottish Government; 2010.

[30] Baranova P, Conway E, Lynch N, Paterson F. The low carbon economy: Understanding and supporting a sustainable transition. 2017. doi:10.1007/978-3-31956753-2.

[31] Garza-Reyes JM-C, Arturo J. Establishing Framework: Sustainable Transition Towards a Low-Carbon Economy. In: Baranova $\mathrm{P}$, Conway E, Lynch $\mathrm{N}$, Paterson F, editors. Low Carbon Econ. Underst. Support. a Sustain. Transit., Derby, UK: Palgrave Macmillan UK; 2017, p. 15-31.

[32] Niamir L, Filatova T, Voinov A, Bressers H. Transition to low-carbon economy: Assessing cumulative impacts of individual behavioral changes. Energy Policy 2018;118:325-45. doi:10.1016/j.enpol.2018.03.045.

[33] Xin X, Yuding W, Jianzhong W. The Problems and Strategies of the Low Carbon Economy Development. Energy Procedia 2011;5:1831-6. doi:10.1016/j.egypro.2011.03.312.

[34] Nyambuu U, Semmler W. Climate Change and the Transition to a Low Carbon Economy -. Econ Model 2019. doi:10.1016/j.econmod.2019.04.026.

[35] Olatunji OO, Ayo OO, Akinlabi S, Ishola F, Madushele $\mathrm{N}$, Adedeji PA. Competitive advantage of carbon efficient supply chain in manufacturing industry. J Clean Prod 2019;238:1-9.

[36] Olatunji OO, Akinlabi SA, Ayo OO, Madushele N, Adedeji PA, Fatoba SO. Drivers and barriers to competitive carbon footprint reduction in manufacturing supply chain: a brief review. 2nd Int. Conf. Sustain. Mater. Process. Manuf., vol. 35, Elsevier B.V.; 2019, p. 992-1000. doi:10.1016/j.promfg.2019.06.047.

[37] OECD. Transition to a Low-Carbon Economy: Public goals and corporate practices. OECD Publishing; 2010. doi:10.1787/9789264090231-en.

[38] Kane G. The three secrets of green business: unlocking competitive advantage in a low carbon economy. London, UK: Earthscan; 2010.

[39] Madushele N, Adedeji PA. Plausibility of assessing environmental impacts of a domestic biogas digester in the design stage. Environ Prog Sustain Energy 2019. doi:10.1002/ep.13228.

[40] DEA. South Africa's Low-Emission Development Strategy 2050. 2018.

[41] Akuru UB, Onukwube IE, Okoro OI, Obe ES. Towards $100 \%$ renewable energy in Nigeria. Renew Sustain Energy Rev 2017;71:943-53. doi:10.1016/j.rser.2016.12.123.

[42] Van der Linde HA. Wind Energy in south Africa. Renew Energy 1996;9:880-3.

[43] Coppez G, Chowdhury S, Chowdhury SP. South African renewable energy hybrid power system storage needs, challenges and opportunities. 2011 IEEE Power Energy Soc Gen Meet 2011:1-9. doi:10.1109/PES.2011.6039336.

[44] Acuna LG, Padilla RV, Mercado AS. Measuring reliability of hybrid photovoltaic-wind energy systems: A new indicator. Renew Energy 2017;106:68-77. doi:10.1016/j.renene.2016.12.089.

[45] Bhandari B, Poudel SR, Lee K-T, Ahn S-H. Mathematical modeling of hybrid renewable energy system: A review on small hydro-solar-wind power generation. Int J Precis Eng Manuf Technol 2014;1:15773. doi:10.1007/s40684-014-0021-4

[46] Astudillo MF, Treyer K, Bauer C, Pineau P-O, Amor M Ben. Life cycle inventories of electricity supply through the lens of data quality: exploring challenges and opportunities. Int J Life Cycle Assess 2017;22:374-86. doi:10.1007/s11367-016-1163-0.

[47] Yasin Sunak, Höfer T, Siddique H, Madlener R, Doncker RW De. A GIS-based Decision Support System for the Optimal Siting of Wind Farm Projects. EON Energy Res Cent Ser 2015;7:41

[48] Szewczuk S. Review of the wind energy activities in South Africa. Green Build. Handb. Volume 6:, 2014, p. $1-10$.

[49] SANEDI. Wind Atlas for South Africa. WASA 2 Final Reports 2018. http://www.wasaproject.info/ (accessed September 29, 2019).

[50] Gulati M, Scholtz L. TIPS Forum 2017 Industrialisation and Sustainable Growth. 2017.

[51] Louise S, Khodani M, Karin K, Mbali M, Stephen F. Renewable Energy : Facts and Futures The energy future we want. vol. 06. 2017.

[52] Sager M. Renewable Energy Vision 2030 - South Africa. 2014

[53] Fluri TP. The potential of concentrating solar power in South Africa. Energy Policy 2009;37:5075-80. doi:10.1016/j.enpol.2009.07.017.

[54] The World Bank. Solar Resource Maps for South Africa. Download Sol Resour Maps GIS Data 180+ Ctries 2017. https://solargis.com/maps-and-gisdata/download/south-africa (accessed September 29, 2019).

[55] Eskom. CONCENTRATING SOLAR POWER ( CSP ). 
2017.

[56] Krupa J, Burch S. A new energy future for South Africa: The political ecology of South African renewable energy. Energy Policy 2011;39:6254-61. doi:10.1016/j.enpol.2011.07.024.

[57] Pollet BG, Staffell I, Adamson KA. Current energy landscape in the Republic of South Africa. Int $\mathbf{J}$ Hydrogen Energy 2015;40:16685-701. doi:10.1016/j.ijhydene.2015.09.141.

[58] Surender R, Noble M, Wright G, Ntshongwana P. Social Assistance and Dependency in South Africa: An Analysis of Attitudes to Paid Work and Social Grants. Jnl Soc Pol 2010;39:203-21. doi:10.1017/S0047279409990638.

[59] Mncwango B. Public Attitudes to Work in South Africa. 2016.

[60] Mncwango B, Winnaar L. South Africans at work : How satisfied are we? 2010.

[61] Inderberg THJ, Tews K, Turner B. Is there a Prosumer Pathway? Exploring household solar energy development in Germany, Norway, and the United Kingdom. Energy Res Soc Sci 2018;42:258-69. doi:10.1016/j.erss.2018.04.006.

[62] Reddy Y, Wolpe P, Cilliers Z. State of energy in South African Cities Report 2015. 2015. doi:10.1038/nj72421208a.

[63] Brown D, Hall S, Davis M. Prosumers in the post subsidy era: an exploration of new prosumer business models in the UK. Energy Policy 2019;135:1-17. doi:10.1016/j.enpol.2019.110984.

[64] Callaghy TM. Lost between state and market: The politics of economic adjustment in Ghana, Zambia, and Nigeria. In: Nelson J, editor. IThe Polit. Econ. Adjust. third world, Princeton NJ: Princeton University Press.; 1990, p. 257-320.

[65] Erdogdu E. A cross-country analysis of electricity market reforms: Potential contribution of New Institutional Economics. 2002.

[66] Gore CD, Brass JN, Baldwin E, Maclean LM. Political autonomy and resistance in electricity sector liberalization in Africa. World Dev 2018. doi:10.1016/j.worlddev.2018.03.003.

[67] Holburn GLF. Assessing and managing regulatory risk in renewable energy : Contrasts between Canada and the United States. Energy Policy 2012;45:654-65. doi:10.1016/j.enpol.2012.03.017.

[68] de Jongh D, Ghoorah D, Makina A. South African renewable energy investment barriers: An investor perspective. J Energy South Africa 2014;25:15-27.

[69] DME. White Paper on the Energy Policy of the Republic of South Africa. 1998.

[70] Rennkamp B, Haunss S, Wongsa K, Ortega A, Casamadrid E. Competing coalitions: The politics of renewable energy and fossil fuels in Mexico, South Africa and Thailand. Energy Res Soc Sci 2017;34:21423. doi:10.1016/j.erss.2017.07.012.

[71] World Commission on Environment and Development. Our Common Future. Oxford, England: Oxford University Press; 1987.

[72] Tejeda J, Ferreira S. Applying systems thinking to analyze wind energy sustainability. Procedia Comput Sci 2014;28:213-20. doi:10.1016/j.procs.2014.03.027.

[73] Vo HM. EAI Endorsed Transactions Implementing Energy Saving Techniques for Sensor Nodes in IoT Applications 2018;5:1-7.

[74] Peharda D, Ivanković I, Jaman N. Using Data from
SCADA for Centralized Transformer Monitoring Applications. Procedia Eng 2017;202:65-75. doi:10.1016/j.proeng.2017.09.695.

[75] Dai J, Yang X, Hu W, Wen L, Tan Y. Effect investigation of yaw on wind turbine performance based on SCADA data. Energy 2018;149:684-96. doi:10.1016/j.energy.2018.02.059.

[76] DoE. 2018 South African Energy Sector Report. Department of Energy, South Africa; 2018.

[77] Tanrisever F, Derinkuyu K, Heeren M. Forecasting electricity infeed for distribution system networks: Ananalysis of the Dutch case. Energy 2013;58:247-57. doi:10.1016/j.energy.2013.05.032.

[78] GCIS. 2016/17 South Africa Yearbook. Government Communications (GCIS); 2017.

[79] Marquard A. South Africa and the G20: where do we stand on greenhouse gas emissions? Univ Cape T 2017. https://www.news.uct.ac.za/article/-2017-07-05-southafrica-and-the-g20-where-do-we-stand-on-greenhousegas-emissionsa (accessed August 21, 2018).

[80] Du Plessis W. Energy efficiency and the law: A multidisciplinary approach. S Afr J Sci 2015;111:1-8.

[81] Lezak SB, Thibodeau PH. Systems thinking and environmental concern. J Environ Psychol 2016;46:14353. doi:10.1016/j.jenvp.2016.04.005.

[82] Barton J, Haslett T. Analysis, Synthesis, Systems Thinking and the Scientific Method: Rediscovering the Importance of Open Systems. Syst Res Behav Sci 2007;24:143-55. doi:10.1002/sres. 